\title{
Effect of stocking density of juvenile Arapaima gigas on rearing water quality hematological and biochemical profile, and productive performance
}

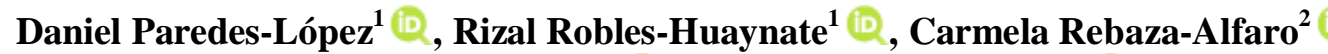 \\ José Delgado-Ramírez ${ }^{2}$ (D) \& Uriel Aldava-Pardave ${ }^{3}(\mathbb{D}$ \\ ${ }^{1}$ Department of Animal Science, Universidad Nacional Agraria de la Selva, Tingo María, Perú \\ ${ }^{2}$ Instituto de Investigación de la Amazonía Peruana-IIAP, Pucallpa, Perú \\ ${ }^{3}$ Escuela de Postgrado, Universidad Nacional Agraria La Molina, Lima, Perú \\ Corresponding author: Daniel Paredes-López (daniel.paredes@ unas.edu.pe)
}

\begin{abstract}
At inadequate stocking density, fish generally show different physiological responses. The effects of stocking density on Arapaima gigas larvae productive parameters have been determined in a previous study. This study aimed to evaluate the effect of the stocking density on the water quality, hematological and biochemical profile, and productive performance of juvenile A. gigas. One hundred and eighty twelve months old, A. gigas were distributed into tanks using initial densities of $103.90,157.95$ and $220.11 \mathrm{~kg} \mathrm{~m}^{-3}$ with three replicates. Ammoniacal nitrogen, carbon dioxide, dissolved oxygen $\mathrm{pH}$, alkalinity, and hardness were determined using a LaMotte Fish Farm 9, AQ-2 model, Maryland, USA, freshwater test kit. Blood samples were taken at 13, 14, and 15 months old by pricking the caudal vein and profiles of glucose (Glu), total protein (TP), albumin, aspartate transaminase (AST), alanine transaminase (ALT), and urea, were determined in blood serum. Rearing water was saturated in ammoniac nitrogen, carbon dioxide, and dissolved oxygen but have not changed with the increase of stocking density $(P<0.05)$, Erythrocyte's count $(\mathrm{EC})$ diminished $(P<0.05)$, nonetheless, hemoglobin, mean concentration hemoglobin $(\mathrm{MCH})$ and mean cell volume $(\mathrm{MCV})$ increased $(P<0.05)$. Albumin, AST, ALT and urea diminished at $220.11 \mathrm{~kg} \mathrm{~m}^{-3}$ stocking density $(P<0.05)$. The feed intake increased, final biomass gain was $100.26 \pm 19.00,119.10 \pm 13.95$, and $130.24 \pm 08.07 \mathrm{~kg} \mathrm{~m}^{-3}$, but did not change as density increased $(P<0.05)$. Juveniles of $A$. gigas showed no variation in productive performance with an increase in the stocking density. Furthermore, hematological and biochemical adapting profile to high stocking densities characterized this species.
\end{abstract}

Keywords: Arapaima gigas; fish farming; fish performance; intensive rearing; aquaculture

\section{INTRODUCTION}

Stocking density is, after feeding and nutrition, the most influential factor on the performance of most aquaculture species (Andrade et al. 2015, MillánCubillo et al. 2016, Arifin et al. 2017, 2019, Shajib et al. 2017, Liu et al. 2019, Long et al. 2019, Lorenzen \& Camp 2019). It determines, first of all, the quality of the rearing environment, and second, influence the comfort of the animals in their feeding, movement, resting (MacIntyre et al. 2008, Person-Le Ruyet et al. 2008, Tsuzuki et al. 2008, Pinho et al. 2016, Costa et al. 2017) and thus the importance of studying in aquaculture.

Fishes, in the same way as land species, can suffer considerable changes to their hematological and bioche- mical profiles and other physiological aspects when factors that intervene in their development are not found to be in balance (Braun et al. 2010a, Ferri et al. 2011, Skov et al. 2011, Paredes et al. 2013, Refaey et al. 2018, Da Costa et al. 2019). The hematological results provide us information about the ecosystem's health conditions in which the fish grow.

Arapaima gigas presents special physiological conditions such as aerial breathing, which allow for their adaptation in poorly oxygenated water or with a great concentration of $\mathrm{CO}_{2}$, ammonium, nitrites, and nitrates (Cavero et al. 2004, Sanguino 2007). Few studies have been carried out to date for ex ploring these physiological conditions to improve production rates of this species (Santana et al. 2020). Therefore, studying

Corresponding editor: Mauricio Laterça 
stocking density during different development phases of A. gigas is a factor that is yet to be determined, and it may have direct repercussions on behavior, biochemical physiology, and the productive performance indices (De Oliveira et al. 2012).

This study's objective was to evaluate the stocking density's effect on the water quality, hematological and biochemical profiles, and productive performance of juvenile A. gigas.

\section{MATERIALS AND METHODS}

\section{Fish rearing and feeding}

Rearing of juveniles in the present study took place in the aquaculture laboratory at the Instituto de Investigaciones de la Amazonía Peruana (IIAP), Pucallpa, Peru. Nine cylindrical tanks with a $0.33 \mathrm{~m}^{3}$ capacity were used, to which groundwater was supplied, in a continuous flow of $7.2 \mathrm{~L} \mathrm{~min}^{-1}$ and at $26^{\circ} \mathrm{C}$ average temperature.

One hundred and eighty twelve-month-old juvenile Arapaima gigas were placed at initial densities of 103.90 (D1), 157.95 (D2), and $220.11 \mathrm{~kg} \mathrm{~m}^{-3}$ (D3) with three replicates each. Juveniles had an average of 65.61 $\pm 0.61 \mathrm{~cm}$ length and $2.08 \pm 0.16 \mathrm{~kg}$ weight for D1; $67.69 \pm 1.09 ; 2.37 \pm 0.16 \mathrm{~kg}$ for $\mathrm{D} 2 ; 68.97 \pm 2.0 \mathrm{~cm}$ and $2.64 \pm 0.16 \mathrm{~kg}$ for D3. For feeding was used a diet of $45 \%$ protein, $10 \%$ fat, $2.5 \%$ crude fiber, $12 \%$ humidity, $12 \%$ ash, and $10 \mathrm{~mm}$ particle size (Table 1) and at a rate of $3 \%$ of their biomass and supplied four times per day. For the three densities, a period of one-month adaption to the pond conditions was given (12 months old), and the juvenile A. gigas were reared for 90 days.

\section{Water quality}

Fifty-four water samples distributed three samples per treatment -one per replicate pond- and taken every 15 days during the three months experimental period were analyzed. In each water sample, $\mathrm{pH}$, alkalinity, hardness, dissolved oxygen, carbon dioxide, and ammoniacal nitrogen (Wedemeyer 1996, Boyd 2012) were measured using a Fish Farm 9 de LaMotte AQ-2 model freshwater testing kit, Maryland, USA. Data was recorded at 13, 14, and 15 months old.

\section{Hematological and biochemical profiles}

One hundred and eight blood samples were obtained by puncturing the caudal vein with a syringe at a volume of $4 \mathrm{~mL}$ and later transferring it to two test tubes, one with 2\% EDTA for hematology profiles and the other for coagulating and blood serum obtained for biochemical profiles.
Hematocrit was determined using the microhematocrit technique at 11,000 rpm in a Kert Lab Tom's USA Science Tech Group centrifuge, and the hemoglobin was determined using the cyanmethemoglobin method (Samour et al. 2016) and quantified using a DIALAB DTN 405 spectrophotometer at $530 \mathrm{~nm}$. The mean cell hemoglobin concentration (MCHC), mean cell hemoglobin $(\mathrm{MCH})$ and mean cell volume (MCV) indices were calculated from the total counts of erythrocytes, hematocrits, and hemoglobin. The total leukocytes (TL), differential leukocyte counting, and grouped in granulocytes (GRA), and lymphocytes (L), and total erythrocytes (TE) were evaluated using Natt-Herrick staining and the procedure modified by Law (Noga 2010, Grant 2015).

The biochemical profiles were determined from samples of blood serum. To obtain these, first, the blood was coagulated and then centrifuged at $1500 \mathrm{rpm}$ for $3 \mathrm{~min}$. It was placed in microtubes and stored at $40^{\circ} \mathrm{C}$ until it was processed. The glucose, protein, albumin, aspartate transaminase (AST), and alanine transaminase (ALT) profiles were determined using Wiener Lab reactors, a DIALAB DTN 405 spectrophotometer, and $530 \mathrm{~nm}$ filters were used. The hematological and biochemical profiles were evaluated at 13,14 , and 15 months old.

\section{Productive performance}

Before taking fish measurements and drawing blood, the randomly selected fish per replicate pond were submerging them in a solution of $5 \mathrm{~g}$ of $\mathrm{NaCl} \mathrm{L}{ }^{-1}$ for 5$10 \mathrm{~min}$ to alleviate or reduce osmoregulatory dysfunction by decreasing the gradient between the water and the fish blood during handling stress period (Wurts 1995, Harmon 2009). Weight gain, feed intake, biomass gain, was recorded at 13,14 , and 15 months old. Feed conversion rate, absolute growth rate, relative growth rate, specific growth rate were determined at the end of the experimental period (Lugert et al. 2014).

\section{Statistical analysis}

The juvenile A. gigas were distributed using the completely randomized design with three treatments and three replicates each. For the bio-chemical profiles, the results were analyzed using a completely randomized design with a factorial arran-gement of $3 \times 3$ (three evaluations and three densities). For this data and those for productive performance parameters, ANOVA was applied using the Infostat (UNC 2016) statistical software, and for multiple comparisons, the Tuckey test $(P<0.05)$ was applied. 
Table 1. Proximal analysis of Arapaima gigas diet from 12 to15 months old.

\begin{tabular}{cccccc}
\hline Protein $(\%)$ & Fat $(\%)$ & Crude fiber (\%) & Humidity (\%) & Ash (\%) & Particle (mm) \\
\hline 45.0 & 10.0 & 2.5 & 12.0 & 12.0 & 10.0 \\
\hline
\end{tabular}

\section{RESULTS}

\section{Water quality}

Dissolved oxygen was at a minimum, carbon dioxide and ammoniac nitrogen were in maximum levels tolerated by fish in the rearing water (Boyd 2012). However, none of the analyzed water components varied with the increase in stocking density of juvenile Arapaima gigas $(P>0.05)$ (Table 2$)$.

\section{Hematological and biochemical profiles}

Total erythrocyte count decreased associated with the increase in stocking density $(P<0.05)$, nonetheless, the hemoglobin increased as the stocking density increased $(P<0.05)$, and hematocrit did no vary $(P>0.05)$ (Table $3)$.

Mean corpuscular hemoglobin and mean corpuscular volume showed an increase as stocking density increased $(P<0.05)$, however, the mean corpuscular hemoglobin concentration showed no variation $(P>$ $0.05)$. The total number of leukocytes and granulocytes increased as the stocking density increased $(P<0.05)$, however, lymphocytes decreased $(P<0.05)$ (Table 3$)$.

Albumin, aspartate transaminase, alanine transaminase, and urea decreased with the greater stocking density $(P<0.05)$, nonetheless, the stocking density did no influenced the glucose and protein profiles $(P>$ 0.05) (Table 4).

\section{Productive performance}

In this study feed intake increased as stocking density increased $(114.88 \pm 1.17,156.42 \pm 1.67$, and $184.08 \pm$ $4.30 \mathrm{~kg})(P<0.05)$, on the other hand, stocking density had no effect on weight gain $(2.01 \pm 0.19,1.79 \pm 0.19$, $1.57 \pm 0.23 \mathrm{~kg})$, biomass gain $(100.26 \pm 19.00,119.10$ \pm 13.95 and $\left.130.24 \pm 08.07 \mathrm{~kg} \mathrm{~m}^{-3}\right)$, feed conversion rate $(1.15 \pm 0.26,1.31 \pm 0.29$ and $1.41 \pm 0.36)$, relative growth rate $(1.08 \pm 0.26,0.84 \pm 0.12$ and $0.66 \pm 0.03 \%$ $\left.90 \mathrm{~d}^{-1}\right)$, absolute growth rate $(0.02 \pm 0.00,0.02 \pm 0.00$ and $\left.0.02 \pm 0.00 \mathrm{~kg} \mathrm{~d}^{-1}\right)$, and specific growth rate $(3.18$ $\left.\pm 0.27,3.21 \pm 0.21,3.27 \pm 0.23 \% \mathrm{~d}^{-1}\right)$ of $A$. gigas $(P>$ 0.05) (Table 5).

\section{DISCUSSION}

Any decision to increase biomass production in aquaculture by increasing fish density should consider the physiological stress that the fish are subjected to and any factors that may adversely affect their health (Ni et al. 2014, Plăcintă et al. 2014, Ajani et al. 2015, Arifin et al. 2019, Liu et al. 2019).

In this study, instead of the no variation of water quality parameters with an increase in the stocking density of juvenile A. gigas $(P>0.05)$ (Table 2), ammoniacal nitrogen, carbon dioxide was several times higher and dissolved oxygen three-fold lower in the rearing water than those showed in A. gigas reared at one fish $10 \mathrm{~m}^{-2}$ (Ferreira-Lima 2020). These results were also similar to those shown in A. gigas by Delgado-Ramirez et al. (2013), rearing 125, 250, and 375 fingerlings $\mathrm{m}^{-3}$ and those results obtained with juvenile Brycon orthotaenia at densities of 150, 300,

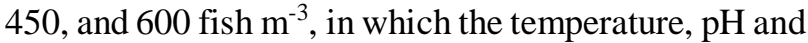
oxygen concentration of the water was reported to be similar among the groups (Lago et al. 2014).

Those are different from the results obtained by $\mathrm{Da}$ Costa et al. (2019) with juvenile tambaqui (Colossoma macropomum) where showed a decrease gradually in the $\mathrm{pH}$ and $\mathrm{O}_{2}$ level from $8 \mathrm{mg} \mathrm{L}^{-1}$ in $2.11 \mathrm{~kg} \mathrm{~m}^{-3}$ to 5 $\mathrm{mg} \mathrm{L}^{-1}$ in $27.40 \mathrm{~kg} \mathrm{~m}^{-3}$ stocking densities and the ammonia level increase from $0.2 \mathrm{mg} \mathrm{L}^{-1}$ in the lower density to $1.0 \mathrm{mg} \mathrm{L}^{-1}$ in the higher density.

Tolerance of A. gigas to very high levels of ammoniacal nitrogen, carbon dioxide, and very low dissolved oxygen levels showed in this study may be because fish of the Amazonas has developed a series of coordinated metabolic adjustments. Which coordinated with morphological and anatomical changes as the airbreathing, has resulted in several solutions to avoid stress caused by warm water ponds (De Almeida-Val et al. 2006, Lam et al. 2006, MacIntyre et al. 2008).

Specifically, in A. gigas, it may be due to the nature of this species respiration, which does not exclusively use the oxygen from the water; therefore, the lower levels of $\mathrm{O}_{2}$ and higher levels of residual $\mathrm{CO}_{2}$ within the warm water ponds do not have a negative effect in Amazon fishes (Brauner \& Val 2006, Sanguino 2007). Maybe because of this fish's efficiency for feeding and not wasting feed in his environment and the flowing of rearing waste by the circulation of water which was $7 \mathrm{~L}$ $\mathrm{min}^{-1}$ in the rearing system.

Very dynamic physiological mechanisms produce the hematological profiles; thus, they are very susceptible to variation when the organism is exposed to 
Table 2. Water quality from the rearing ponds of juvenile Arapaima gigas at different stocking densities, from 13 to 15 months old as an average of the three months data (mean \pm standard deviation). Different letters within rows denote a significant difference, $\alpha=0.05$ (Tukey test).

\begin{tabular}{lcrrr}
\hline \multirow{2}{*}{ Parameters } & ANOVA & \multicolumn{3}{c}{ Stocking density } \\
\cline { 3 - 5 } & $(P$-value $)$ & $103.90 \mathrm{~kg} \mathrm{~m}^{-3}$ & $157.95 \mathrm{~kg} \mathrm{~m}^{-3}$ & $220.11 \mathrm{~kg} \mathrm{~m}^{-3}$ \\
\hline Dissolved oxygen $\left(\mathrm{mg} \mathrm{O}_{2} \mathrm{~L}^{-1}\right)$ & 0.247 & $2.34 \pm 0.39$ & $1.99 \pm 0.04$ & $2.03 \pm 0.17$ \\
Ammonium $\left(\mathrm{mg} \mathrm{NH}_{4} \mathrm{~L}^{-1}\right)$ & 0.268 & $2.21 \pm 0.38$ & $2.38 \pm 0.13$ & $2.57 \pm 0.12$ \\
Carbon dioxide $\left(\mathrm{mg} \mathrm{CO}_{2} \mathrm{~L}^{-1}\right)$ & 0.809 & $15.33 \pm 0.76$ & $15.67 \pm 1.28$ & $15.92 \pm 1.13$ \\
$\mathrm{pH}$ & 0.214 & $6.96 \pm 0.07$ & $7.04 \pm 0.07$ & $7.07 \pm 0.06$ \\
Alkalinity $\left(\mathrm{mg} \mathrm{CaCO}_{3} \mathrm{~L}^{-1}\right)$ & 0.091 & $171.50 \pm 3.28$ & $164.67 \pm 3.40$ & $163.67 \pm 4.73$ \\
Hardness $\left(\mathrm{mg} \mathrm{CaCO}_{3} \mathrm{~L}^{-1}\right)$ & 0.647 & $71.17 \pm 2.02$ & $73.25 \pm 3.88$ & $72.50 \pm 1.50$ \\
\hline
\end{tabular}

Table 3. Hematological profiles and erythrocytes indices of juvenile Arapaima gigas at different stocking densities, from 13 to 15 months old as an average of the three months data (mean \pm standard deviation). MCV: mean corpuscular volume, MCH: mean cell hemoglobin, MCHC: mean cell hemoglobin concentration. Different letters within rows denote significant difference, $\alpha=0.05$ (Tukey test).

\begin{tabular}{lcccc}
\hline \multirow{2}{*}{ Parameters } & ANOVA & \multicolumn{3}{c}{ Stocking density } \\
\cline { 3 - 5 } & $(P$-value $)$ & $103.90 \mathrm{~kg} \mathrm{~m}^{-3}$ & $157.95 \mathrm{~kg} \mathrm{~m}^{-3}$ & $220.11 \mathrm{~kg} \mathrm{~m}^{-3}$ \\
\hline Hemoglobin $\left(\mathrm{g} \mathrm{dL}^{-1}\right)$ & 0.001 & $10.78 \pm 0.58^{\mathrm{b}}$ & $11.05 \pm 0.63^{\mathrm{b}}$ & $11.86 \pm 0.76^{\mathrm{a}}$ \\
Hematocrit $(\%)$ & 0.129 & $35.28 \pm 3.22$ & $34.92 \pm 2.55$ & $37.43 \pm 3.96$ \\
Erythrocytes $\left(10^{6} \mu \mathrm{L}^{-1}\right)$ & 0.005 & $1.91 \pm 0.19^{\mathrm{a}}$ & $1.66 \pm 0.20^{\mathrm{b}}$ & $1.66 \pm 0.17^{\mathrm{b}}$ \\
MCV $(\mathrm{fL})$ & 0.016 & $196.23 \pm 22.55^{\mathrm{b}}$ & $221.95 \pm 28.55^{\mathrm{ab}}$ & $230.80 \pm 27.86^{\mathrm{a}}$ \\
MCH $(\mathrm{pg})$ & 0.002 & $61.10 \pm 08.30^{\mathrm{b}}$ & $70.39 \pm 08.83^{\mathrm{a}}$ & $73.59 \pm 06.48^{\mathrm{a}}$ \\
MCHC $\left(\mathrm{g} \mathrm{dL}^{-1}\right)$ & 0.879 & $32.15 \pm 04.09$ & $32.54 \pm 03.54$ & $33.02 \pm 04.56$ \\
Leukocytes $\left(10^{3} \mu \mathrm{L}^{-1}\right)$ & 0.000 & $11.52 \pm 2.22^{\mathrm{b}}$ & $09.80 \pm 1.98^{\mathrm{b}}$ & $15.01 \pm 2.90^{\mathrm{a}}$ \\
Granulocytes $(\%)$ & 0.000 & $55.64 \pm 02.25^{\mathrm{b}}$ & $62.86 \pm 01.93^{\mathrm{a}}$ & $60.98 \pm 03.75^{\mathrm{a}}$ \\
Lymphocytes $(\%)$ & 0.000 & $45.69 \pm 2.07^{\mathrm{a}}$ & $37.13 \pm 1.92^{\mathrm{b}}$ & $39.22 \pm 3.98^{\mathrm{b}}$ \\
\hline
\end{tabular}

extrinsic as well as intrinsic factors, and thus, they are very important markers for interpreting the response of the organism, as is the case here, under the effect of the rearing density factor (Davis et al. 2008).

Total erythrocytes showed to be different from those obtained in studies with Clarias gariepinus, an African air-breathing fish (Dai et al. 2011), and in a study in C. macropomum (Da Costa et al. 2019), where the number of erythrocytes did not vary with the stocking densities. In the same way, this study contrasts with the results in Centropomus parallelus, where total erythrocytes were higher at 500 fish $\mathrm{m}^{-3}$ compared to 200 and 350 fish $\mathrm{m}^{-3}$ in a recirculation rearing system (Pinho et al. 2016). It is known that the level of erythrocytes in fish and other vertebrae is associated with their activity, which is to say, sedentary fish have lower levels of erythrocytes than those which are more active (Claver \& Quaglia 2009).

An increase in hemoglobin, $\mathrm{MCH}$, and $\mathrm{MCV}$ as $A$. gigas stocking density increased may be as a negative feedback response to a decrease in total erythrocyte count and no change in hematocrit level and MCHC (Reece 2015). Different results in hemoglobin, $\mathrm{MCH}$, and MCV and similar results in MCHC of this study have been reported in $C$. gariepinus, where these profiles did not change with increasing density from 35 to $125 \mathrm{~kg} \mathrm{~m}^{-3}$ (Dai et al. 2011) and in C. macroporum at $2.11,8.41,16.34$ and $27.34 \mathrm{~kg} \mathrm{~m}^{-3}$ densities (Da Costa et al. 2019).

The hematological profiles, as well as the hematological indices, in general, increased as a function of the age of $A$. gigas $(P<0.05)$ due to physiological mechanisms, which cause them to be more adapted as they reach the adult state (Reece 2015).

The increase in total leukocytes and granulocytes as stocking density increased $(P<0.05)$ is a favorable response to a stimulus caused by stress in an acute form, as is the case in a state of overpopulation (Tort 2011). Nonetheless, when the overpopulation in fish is prolonged, on the contrary, the immune response diminishes (Caipang et al. 2009), and it may explain lowering lymphocytes as the stocking density increased in this research $(P<0.05)$. Similar results have been shown in C. macropomum (Da Costa et al. 2019).

The difference in the hematological profiles and indices obtained in the present research from those 
Table 4. Biochemical profiles of juveniles Arapaima gigas at different stocking densities, from 13 to 15 months old (mean \pm standard deviation). Different letters within rows denote significant differences $(P<0.05)$. AST: aspartate transaminase, ALT: alanine transaminase, $\mathrm{IU} \mathrm{L}^{-1}$ : international unit, VC: variation coefficient.

\begin{tabular}{|c|c|c|c|c|c|c|}
\hline \multirow[b]{2}{*}{ Factors } & \multicolumn{6}{|c|}{ Parameters } \\
\hline & $\begin{array}{l}\text { Glucose } \\
\left(\mathrm{g} \mathrm{dL}^{-1}\right)\end{array}$ & $\begin{array}{l}\text { Protein } \\
\left(\mathrm{g} \mathrm{dL}^{-1}\right)\end{array}$ & $\begin{array}{c}\text { Albumin } \\
\left(\mathrm{g} \mathrm{dL}^{-1}\right)\end{array}$ & $\begin{array}{c}\text { AST } \\
\left(\text { IU L L }^{-1}\right)\end{array}$ & $\begin{array}{c}\text { ALT } \\
\left(\text { IU L }^{-1}\right)\end{array}$ & $\begin{array}{c}\text { UREA } \\
\left(\mathrm{mg} \mathrm{L}^{-1}\right)\end{array}$ \\
\hline \multicolumn{7}{|l|}{ Density } \\
\hline $103.90 \mathrm{~kg} \mathrm{~m}^{-3}$ & $31.04 \pm 10.1$ & $2.89 \pm 0.6$ & $1.36 \pm 0.4^{\mathrm{ab}}$ & $20.65 \pm 6.1^{\mathrm{ab}}$ & $16.61 \pm 4.0^{\mathrm{a}}$ & $8.49 \pm 5.5^{\mathrm{a}}$ \\
\hline $157.95 \mathrm{~kg} \mathrm{~m}^{-3}$ & $29.43 \pm 10.0$ & $2.76 \pm 0.4$ & $1.41 \pm 0.3^{\mathrm{a}}$ & $22.56 \pm 7.9^{a}$ & $14.00 \pm 3.5^{\mathrm{b}}$ & $6.48 \pm 3.0^{\mathrm{c}}$ \\
\hline $220.11 \mathrm{~kg} \mathrm{~m}^{-3}$ & $28.55 \pm 8.4$ & $2.76 \pm 0.4$ & $1.31 \pm 0.3^{\mathrm{b}}$ & $19.47 \pm 6.2^{\mathrm{b}}$ & $14.61 \pm 4.1^{\mathrm{ab}}$ & $7.11 \pm 3.7^{b}$ \\
\hline \multicolumn{7}{|l|}{ Age } \\
\hline 13 months & $25.83 \pm 12.2^{\mathrm{b}}$ & $2.41 \pm 0.3 \mathrm{c}$ & $1.01 \pm 0.1 \mathrm{c}$ & $28.144 \pm 4.7 \mathrm{a}$ & $15.99 \pm 5.5$ & $2.32 \pm 0.4 \mathrm{~d}$ \\
\hline 14 months & $34.50 \pm 8.6^{\mathrm{a}}$ & $2.88 \pm 0.2 b$ & $1.35 \pm 0.1 b$ & $22.19 \pm 4.1 b$ & $14.97 \pm 3.7$ & $5.27 \pm 1.1 \mathrm{c}$ \\
\hline 15 months & $29.63 \pm 5.7^{\mathrm{ab}}$ & $2.58 \pm 0.3 \mathrm{c}$ & $1.28 \pm 0.1 \mathrm{~b}$ & $18.47 \pm 6.8 \mathrm{c}$ & $14.97 \pm 3.3$ & $11.37 \pm 3.7 \mathrm{a}$ \\
\hline \multicolumn{7}{|c|}{ ANOVA $(P$-value $)$} \\
\hline Density & 0.316 & 0.1422 & 0.0261 & 0.014 & 0.0073 & 0.0001 \\
\hline Age & 0.0002 & 0.0001 & 0.0001 & 0.0001 & 0.4211 & 0.0001 \\
\hline Density $\times$ age & 0.0001 & 0.0284 & 0.0098 & 0.0091 & 0.0027 & 0.0001 \\
\hline $\mathrm{VC}(\%)$ & 23.59 & 11.27 & 10.87 & 21.17 & 23.95 & 15.15 \\
\hline
\end{tabular}

Table 5. Productive parameters of juvenile Arapaima gigas at different stocking densities from 13 to 15 months old as an average of the three months data (mean \pm standard deviation). WG: weight gain, BG: biomass gain, FCR: feed conversion rate, AGR: absolute growth rate, RGR: relative growth rate, SGR: specific growth rate. Different letters between rows denote significant difference, $\alpha=0.05$ (Tukey test).

\begin{tabular}{lcccc}
\hline \multirow{2}{*}{ Parameter } & \multirow{2}{*}{ ANOVA $(P$-value $)$} & \multicolumn{3}{c}{ Stocking density } \\
\cline { 3 - 5 } & 0.285 & $103.90 \mathrm{~kg} \mathrm{~m}^{-3}$ & $157.95 \mathrm{~kg} \mathrm{~m}^{-3}$ & $220.11 \mathrm{~kg} \mathrm{~m}^{-3}$ \\
\hline WG $(\mathrm{kg})$ & 0.106 & $100.26 \pm 0.19$ & $1.79 \pm 0.19$ & $1.57 \pm 0.23$ \\
BG $\left(\mathrm{kg} \mathrm{m}^{-3}\right)$ & 0.000 & $114.88 \pm 1.17^{\mathrm{c}}$ & $119.10 \pm 13.95$ & $130.24 \pm 08.07$ \\
Feed intake $(\mathrm{kg})$ & 0.281 & $1.15 \pm 0.26$ & $1.31 \pm 0.29$ & $184.08 \pm 4.30^{\mathrm{a}}$ \\
FCR & 0.190 & $0.02 \pm 0.00$ & $0.02 \pm 0.00$ & $0.02 \pm 0.00$ \\
AGR $\left(\mathrm{kg} \mathrm{d}^{-1}\right)$ & 0.056 & $1.08 \pm 0.26$ & $0.84 \pm 0.12$ & $0.66 \pm 0.03$ \\
RGR $\left(\% 90 \mathrm{~d}^{-1}\right)$ & 0.878 & $3.18 \pm 0.27$ & $3.21 \pm 0.21$ & $3.27 \pm 0.23$ \\
SGR $\left(\% \mathrm{~d}^{-1}\right)$ & & & & \\
\hline
\end{tabular}

obtained in previous ones in other related species could be associated with high biomass levels (initial 103.90, $157.95,220.11 \mathrm{~kg} \mathrm{~m}^{-3}$, and final 204.15, 277.06, 350.36 $\mathrm{kg} \mathrm{m}^{-3}$ ) used in this study as well as the air-breathing physiological mechanisms of A. gigas. Like the airbreathing fish Megalops cyprinoides, whose blood possesses up to $50 \%$ less affinity to oxygen than the blood of those species that breath in the water (Wells et al. 2005, Brauner \& Val 2006).

The effect of stocking density in decreasing AST and ALT profiles $(P<0.01)$ in this study may be associated with physiological mechanisms related to the healthy organism of $A$. gigas evidenced by means no morbidity and no mortality, which makes this species tolerant to the effects caused by the increase in stocking density compared to those shown in Ictalurus punctatus (Refaey et al. 2018). These enzymes are localized into the cytoplasm, principally of the hepa- tocytes and myocytes of the different animal species. They could increase their release in the blood when these tissues suffer alterations to the cellular membrane, as is the case in the inflammatory processes or necrosis (Hoffman \& Solter 2008).

In all animal species and especially fish, the level of nitrogenous wastes in blood comes from the degradation of protein and catabolism of amino acids from the diet, and therefore the higher intake of diet, the higher the synthesis of nitrogen as waste in the blood (Ip \& Chew 2018). In this study, the high level of ammoniacal nitrogen in rearing water may be associated with increased feed intake as stocking density increased.

The majority of teleost synthesize ammonia predominantly as an end product for excreting nitrogenous waste (ammoniotelic); however, some of them may increase urea synthesis for excretion or become 
transiently ureotelic after feeding, exposed to elevated water ammonia, confinement, or crowding (Wright \& Land 1998, Braun \& Perry 2010b, McDonald et al. 2012, Chew \& Ip 2014). Therefore, the high levels of urea in blood of $A$. gigas in this study and the change of urea levels as the stocking density increased may be associated with the high level of ammoniacal nitrogen (1.99-2.36 $\mathrm{mg} \mathrm{L}^{-1}$ ) and the trend of increase, although no statistically significant of this nitrogen waste in the rearing water as the stocking density of A. gigas increased.

Glucose and total protein profiles in the blood serum of A. gigas were similar at the three density levels; however, these profiles showed an interaction between age and stocking density $(P<0.05)$ (Table 4$)$. The increase of glucose in fish, before the effect of the stress factor, is since they use it to compensate for the increase in energy demand for swimming and other activities to face the disturbance in the environment (Polakof et al. 2011). Nonetheless, the levels of glucose under the effects of density in fish differ based upon the species. In Acipenser schrenckii, the glucose levels were similar at low, medium, and high densities (Ni et al. 2014), but in Gadus morhua and Acipenser sinensis, glucose increased as the density increased (Caipang et al. 2009, Long et al. 2019).

Total protein and albumin in the blood generally are associated with the level of non-specific immunity and is made up of lysozymes, complement, and the levels under the effect of stress factors, such as the increase in stocking density of fish, generally increase (Ortuño et al. 2001, Tort 2011, Ni et al. 2014). However, the response varies with the species. In Gadus morhua and A. sinensis, protein levels were similar at two and three densities, respectively (Caipang et al. 2009, Long et al. 2019). The no variation of glucose and total protein profile instead of lowering the albumin profile by the effect of stocking density $(P<0.05)$ (Table 4$)$, may evidence that $A$. gigas poses adapting physiological mechanisms to overcome the stressful impact caused by the increase in stocking density such as secreting less cortisol as stocking density increase in larvae (Santana et al. 2020).

Glucose, protein, and albumin profiles, in general, increased as a function of the age of $A$. gigas due to physiological mechanisms, which become more efficient, just like the hematological responses, as they arrive at an adult state, in different animal species (Eckersall 2008). All the biochemical profiles from this study were within the species' physiological profiles (Tavares-Dias et al. 2007, Paredes et al. 2013).

In general, in all species of animal for production, including fish, a high stocking density is associated with a decrease in growth, weight gain, and feed conversion rate (Tong et al. 2012, Ardiansyah \& Fotedar 2016, Fu et al. 2016, Costa et al. 2017, Reafey et al. 2018, Liu et al. 2019, Long et al. 2019). However, in this study, A. gigas showed a different pattern, weight gain, feed conversion rate, absolute growth rate, specific growth rate, feed conversion rate, biomass gain, and relative growth rate did not change under the effect of increasing stocking density. These results are supported by another study where the lowest cortisol plasma level and higher performance variables of the $A$. gigas larvae reared at the 2000 larvae $\mathrm{m}^{-3}$ density than those at 400, 800, 1200, and 1600 larvae $\mathrm{m}^{-3}$ have been reported (Santana et al. 2020), suggesting that these conditions may contribute to the welfare of A. gigas to be better at higher densities than lower densities.

It is also in line with the study where size grading did not change final biomass, feed conversion rate, and specific growth rate in A. gigas (Ferreira Lima et al. 2020) and the study in C. macropomum where stocking density had no effect on the final weight and feed conversion rate (Costa et al. 2016).

At the same time, it contrasts with results in other studies of this species in which stoking density affected final weight and weight gain, and production was no affected (De Oliveira et al. 2012). In this way, other different results have been obtained in Salminus brasiliensis (Braun et al. 2010a), in C. gariepinus (Toko et al. 2007), in Brycon insignis (Tolussi et al. 2010).

These results in A. gigas could be narrowly associated with the physiological mechanisms such as the increase in the blood profiles, which are directly related to metabolism, as are hemoglobin, $\mathrm{MCH}$, and MCV (Noga 2010, Grant 2015), which increased with the stocking density in this study. At the same time, this may be associated with physiological mechanisms such as A. gigas respiration, in which the blood possesses up to fifty percent less affinity for oxygen than the blood of those species that breath in the water (Brauner \& Val 2006). Both mechanisms would make A. gigas more efficient in overcoming the negative effects of the increase in the stocking density, which are shown in other species of fish.

\section{CONCLUSIONS}

A. gigas showed hematological and biochemical adaptation and no variation in productive performance under the effects of the stocking density. This research evidenced that $A$. gigas is a species with great production potential due to its physiological capacity to adapt to higher stocking densities than other fish species, and it needs further research. 


\section{ACKNOWLEDGEMENTS}

The authors express their gratitude to the Universidad Nacional Agraria de la Selva for financing the project through the grant awarded and the Instituto de Investigaciones de la Amazonía Peruana for supporting with field infrastructure. The authors also acknowledge professor Ricardo Oliva-Paredes for his kind support in reviewing the productive performance data.

\section{REFERENCES}

Ajani, E.K., Setufe, S.B. \& Oyebola, O.O. 2015. Effects of stocking density on hematological functions of juvenile African catfish (Clarias gariepinus) fed varying crude protein levels. African Journal of Food Science, 9: 65-69.

Andrade, T., Afonso, A., Pérez-Jiménez, A., Oliva-Teles, A., De las Heras, V., Mancera, J.M., et al. 2015. Evaluation of different stocking densities in a Senegalese sole (Solea senegalensis) farm: implications for growth, humoral immune parameters, and oxidative status. Aquaculture, 438: 6-11.

Ardiansyah \& Fotedar, R. 2016. Water quality, growth and stress response of juvenile barramundi (Lates calcarifer Blotch), reared at four densities in integrated recirculating aquaculture systems. Aquaculture, 458: 113-120.

Arifin, O.Z., Prakoso, V.A., Subagja, J., Kristanto, A.H., Pouil, S. \& Slembrouck, J. 2019. Effects of stocking density on survival, food intake and growth of giant gourami (Osphronemus goramy) larvae reared in a recirculating aquaculture system. Aquaculture, 509: 159-166.

Arifin, O.Z., Subagja, J., Prakoso, V.A. \& Suhud, E.H. 2017. Effect of stocking density on growth performance of domesticated barb (Barbonymus balleroides). Indonesian Aquaculture Journal, 12: 1-6.

Boyd, C. 2012. Water quality. In: Lucas, J.S. \& Southgate, P.C. (Eds.). Aquaculture: farming aquatic animals and plants. Wiley-Blackwell, Oxford, pp. 52-83.

Braun, M.H. \& Perry, S.F. 2010b. Ammonia and urea excretion in the Pacific hagfish Eptatretus stoutii: evidence for the involvement of Rh and UT proteins. Comparative Biochemistry and Physiology - Part A: Molecular \& Integrative Physiology, 157: 405-415.

Braun, N., Lima de Lima, R., Baldisserotto, B., Dafre, A.L. \& De Oliveira Nuñer, A.P. 2010a. Growth, biochemical and physiological response of Salminus brasiliensis with different stock density and handling. Aquaculture, 301: 22-30.
Brauner, C.J. \& Val, A.L. 2006. Oxygen transfer. In: Val, A.L., De Almeida-Val, V.M.F. \& Randall, J.D. (Eds.). The physiology of tropical fishes. Elsevier, Amsterdam.

Caipang, C.M.A., Berg, I., Brinchmann, M.F. \& Kiron, V. 2009. Short-term crowding stress in Atlantic cod Gadus morhua L. modulates the humoral immune response. Aquaculture, 295: 110-115.

Cavero, B.A.S., Pereira-Filho, M., Moreira Bordinhon, A., Da Fonseca, F.A., Ituassú, D.R., Roubach, R. \& Akifumi-Ono, E. 2004. Tolerância de juvenis de pirarucu ao aumento da concentração de amônia em ambiente confinado. Pesquisa Agropecuaria Brasileira, 39: 513-516.

Chew, S.F. \& Ip, Y.K. 2014. Excretory nitrogen metabolism and defense against ammonia toxicity in air-breathing fishes. Journal of Fish Biology, 84: 603638.

Claver, J.A. \& Quaglia, A.I.E. 2009. Comparative morphology, development, and function of blood cells in no mammalian vertebrates. Topics in Medicine and Surgery, 18: 87-97.

Costa, J., Roñan-Freitas, R., Gomes, A.L., Bernadino, G., Carneir, D. \& Martins, M.I. 2016. Effect of stocking density on economic performance for Colossoma macropomum (Cuvier, 1816), juvenile in earthen ponds. Latin American Journal of Aquatic Research, 44: 165-170.

Costa, A.A.P., Roubach, R., Dallago, B.S.L., Bueno, G.W., McManus, C. \& Bernal, F.E.M. 2017. Influence of stocking density on growth performance and welfare of juvenile tilapia (Oreochromis niloticus) in cages. Arquivo Brasileiro de Medicina Veterinária e Zootecnia, 69: 243-251.

Da Costa, O.T.F., Castanhola-Dias, L., Yano-Malmann, C.S., de Lima-Ferreira, C.A., Batista do Carmo, I., Wischneski, I.R., et al. 2019. The effects of stocking density on the hematology, plasma protein profile and immunoglobulin production of juvenile tambaqui (Colossoma macropomum) farmed in Brazil. Aquaculture, 499: 260-268.

Dai, W., Wang, X., Guo, Y., Wang, Q. \& Ma, J. 2011. Growth performance, hematological and biochemical responses of African catfish (Clarias gariepinus) reared at different stocking densities. African Journal of Agricultural Research, 6: 6177-6182.

Davis, A.K., Maney, D.L. \& Maerz, J.C. 2008. The use of leukocyte profiles to measure stress in vertebrates: a review for ecologists. Functional Ecology, 22: 760772.

De Almeida-Val, V.M.F., Chippari-Gómez, A.R. \& PiresLópez, N. 2006. Metabolic and physiological adjustments to low oxygen and high temperature in 
fishes of the Amazon. In: Val, A., De Almeida-Val, V.M.F. \& Randall, D.J. (Eds.). The physiology of tropical fishes. Academic Press, New York, pp. 443500.

Delgado-Ramirez, J., Rebaza-Alfaro, C., Paredes-López, D., Robles-Huaynate, R. \& Bazan-Alvitez, R. 2013. Effect of three densities of culture under laboratory conditions of paiche Arapaima gigas fingerlings on its hematological and biochemical profiles and biometric parameters. Folia Amazónica, 22: 15-24.

De Oliveira, E., Pinheiro, A.B., De Oliveira, V.Q. \& De Moraes, M.G. 2012. Effects of stock density on the performance of juvenile pirarucu (Arapaima gigas) in cages. Aquaculture, 370-371: 96-101.

Eckersall, P.D. 2008. Proteins, proteomics, and dysproteinemias. In: Kaneko, J.J., Harvey, J.W. \& Bruss, M.L. (Eds.). Clinical biochemistry of domestic animals. Academic Press, London, pp. 117-155.

Ferreira-Lima, A. 2020. Effect of size grading on the growth of pirarucu Arapaima gigas reared in earthen ponds. Latin American Journal of Aquatic Research, 4: $165-170$.

Ferri, J., Popovic, N.T., Coz-Rakovac, R. \& Beer-Ljubić, B. 2011. The effect of artificial feed on blood biochemistry profile and liver histology of wild saddled bream, Oblada melanura (Sparidae). Marine Environmental Research, 71: 218-224.

Fu, L., Li, H., Liang, T., Zhou, B., Chu, Q., Schinckel, A.P., et al. 2016. Stocking density affects welfare indicators of growing pigs of different group size after regrouping. Applied Animal Behavior Science, 174: 42-50.

Grant, K.R. 2015. Fish hematology and associated disorders. Veterinary Clinical Exotic Animal, 18: 83101.

Harmon, T.S. 2009. Methods for reducing stressors and maintaining water quality associated with live fish transport in tanks: a review of the basics. Reviews in Aquaculture, 1: 58-66.

Hoffman, W.E. \& Solter, P.F. 2008. Diagnostic enzymology of domestic animals. In: Kaneko, J.J., Harvey, J.W. \& Bruss, M.L. Clinical biochemistry of domestic animals. Academic Press, London, pp. 351378.

Ip, K. \& Chew, S.F. 2018. Air-breathing and excretory nitrogen metabolism in fishes. Acta Histochemica, 120: 680-690.

Lago, A., Fonseca de Freitas, R.T., de Sousa, M.E., Olivetti de Mattos, B., Reis-Neto, R.V. \& CarvalhoCosta, A. 2014. Stocking densities of juvenile Brycon orthotaenia: production parameters and economic benefits in net cages. Animal Sciences, 36: 253-258.

Lam, K., Tsui, T., Nakano, K. \& Randall, D.J. 2006. Physiological adaptations of fishes to tropical intertidal environments. In: Val, A., De Almeida-Val, V.M.F. \& Randall, D.J. (Eds.). The physiology of tropical fishes. Academic Press, New York, pp. 501581.

Liu, Y., Liu, H., Wu, W., Yin, J., Mou, Z. \& Hao, F. 2019. Effects of stocking density on growth performance and metabolism of juvenile lenok (Brachymystax lenok). Aquaculture, 504: 107-113.

Long, L., Zhang, H., Ni, Q., Liu, H., Wu, F. \& Wang, X. 2019. Effects of stocking density on growth, stress, and immune responses of juvenile Chinese sturgeon (Acipenser sinensis) in a recirculating aquaculture system. Comparative Biochemistry and Physiology Part C: Toxicology \& Pharmacology, 219: 25-34.

Lorenzen, K. \& Camp, E.V. 2019. Density-dependence in the life history of fishes: when is a fish recruited? Fisheries Research, 217: 5-10.

Lugert, V., Thaller, G., Tetens, J., Schulz, C. \& Kriete, J. 2014. A review on fish growth calculation: multiple functions in fish production and their specific application. Reviews in Aquaculture, 6: 1-13.

McDonald, M.D., Gilmour, K.M. \& Walsh, P.J. 2012. New insights into the mechanisms controlling urea excretion in fish gills. Respiratory Physiology \& Neurobiology, 184: 241-248.

MacIntyre, C.M., Ellis, T., North, B.P. \& Turnbull, J.F. 2008. The influences of water quality on the welfare of farmed rainbow trout: a review. In: Branson, E.J. (Ed.). Fish welfare. Blackwell Publishing, Oxford, pp. 150184.

Millán-Cubillo, A.F., Martos-Sitcha, J.A., Ruiz-Jarabo, I., Cárdenas, S. \& Mancera, J.M. 2016. Low stocking density negatively affects growth, metabolism, and stress pathways in juvenile specimens of meagre (Argyrosomus regius, Asso 1801). Aquaculture, 451: 87-92.

Noga, E.J. 2010. Fish disease, diagnostic and treatment. Wiley-Blackwell, New Jersey.

Ni, M., Wen, H., Li, J., Chi, M., Bu, Y., Ren, Y., et al. 2014. The physiological performance and immune response of juvenile Amour sturgeon (Acipenser schrenkii) to stocking density and hypoxia stress. Fish \& Shellfish Immunology, 36: 325-335.

Ortuño, J., Esteban, M.A. \& Meseguer, J. 2001. Effect of short-term crowding stress on the gilthead seabream (Sparus aurata L.) innate immune response. Fish \& Shellfish Immunology, 11: 187-197.

Paredes, D., Álvarez, C. \& Valencia, T. 2013. Caracterización hematológica y bioquímica de juveniles de Arapaima gigas "paiche" bajo condiciones de cultivo en selva alta. Investigación y Amazonía, 3: 67-70.

Person-Le Ruyet, J., Labbé, L., Le Bayon, N., Sévère, A., Le Roux, A., Le Delliou, H. \& Quéméner. L. 2008. 
Combined effects of water quality and stocking density on welfare and growth of rainbow trout (Oncorhynchus mykiss). Aquatic Living Resources, 21: 185-195.

Pinho, S., Brol, J., Jacques de Almeida, E., Lemos de Mello, G., Jeronimo, G.T. \& Cohelo-Emerenciano, M.G. 2016. Effect of stocking density and vertical substrate addition on growth, performance, and health status of fat snook Centropomus parallelus. Aquaculture, 457: 73-78.

Plăcintă, S., Cristea, V., Tiberiu, M.C. \& Petrea, S.M. 2014. Hematological profile of juvenile European catfish (Silurus glanis) reared under different stocking densities in recirculating system conditions. Animal Science and Biotechnology, 47: 239-244.

Polakof, S., Mommsen, T.P. \& Soengas, J.L. 2011. Glucosensing and glucose homeostasis: from fish to mammals. Comparative Biochemistry and Physiology - Part B: Biochemistry \& Molecular Biology, 160: 123-149.

Reece, W.O. 2015. The composition and functions of blood. In: Reece, W.O., Erickson, H.H., Goff, J.P. \& Uemura, E.E. (Eds.). Dukes' physiology of domestic animals. Wiley Blackwell, New Jersey, pp. 114-136.

Refaey, M.M., Li, D., Tian, X., Zhang, Z., Zhang, X., Li, L. \& Tang, R. 2018. High stocking density alters growth performance, blood biochemistry, intestinal histology, and muscle quality of channel catfish Ictalurus punctatus. Aquaculture, 492: 73-81.

Samour, J., Silvanose, C. \& Pendl, H. 2016. Clinical and diagnostic procedures. In: Samour, J. (Ed.). Avian medicine. Elsevier, Amsterdam, pp.73-175.

Sanguino, O. 2007. Potencial acuícola de pirarucú (Arapaima gigas) en la cuenca Amazónica. Revista Electrónica de Ingeniería en Producción Acuícola, 2: 9 pp.

Santana, T.M., Elias, A.H., Da Fonseca, F.A.L., Freitas, O.R., Kojima, J.T. \& Gonçalves, L.U. 2020. Stocking density for arapaima larviculture. Aquaculture, 528: 735565.

Shajib, S.H., Sarker, B., Al-Asif, A., Rahman, M., Zafar, A. \& Hossain, A. 2017. Effects of stocking density on the growth rate of goldfish fry reared in hapa. Asian Journal of Medical and Biological Research, 3: 504515.

Skow, P.V., Larsen, B.K., Frisk, M. \& Jokumsen, A. 2011. Effects of rearing density and water current on the respiratory physiology and hematology in rainbow trout, Oncorhynchus mykiss at high temperature. Aquaculture, 319: 446-452.

Received: 17 June 2020; Accepted: 16 September 2020
Tavares-Diaz, M., Barcellos, J.F.M., Marcon, J.L., Menezes, G.C., Ono, E.A. \& Affonso, E.G. 2007. Hematological and biochemical parameters for the pirarucu Arapaima gigas Schinz 1822 (Osteoglossiformes, Arapaimatidae) in net cage culture. Electronic Journal of Ichthyology, 2: 61-68.

Toko, I., Fiogbe, E.D., Koukpode, B. \& Kestemont, P. 2007. Rearing of African catfish (Clarias gariepinus) and vundu catfish (Heterobranchus longifilis) in traditional fishponds (whedos): effect of stocking density on growth, production and body composition, Aquaculture, 262: 65-72.

Tolussi, C.E., Silva-Hilsdorf, A.W., Cannepele, D. \& Guimarães-Moreira, R. 2010. The effects of stocking density in physiological parameters and growth of the endangered teleost species piabanha, Brycon insignis (Steindachner, 1877). Aquaculture, 310: 221-228.

Tong, H.B., Lu, J., Zou, J.M., Wang, Q. \& Shi, S.R. 2012. Effects of stocking density on growth performance, carcass yield, and immune status of a local chicken breed. Poultry Science, 91: 667-673.

Tort, L. 2011. Stress and immunomodulation in fish. Development and Comparative Immunology, 35: 1366-1375.

Tzuzuki, M.Y., Cardoso, R.F. \& Cerqueira, V.R. 2008. Growth of juvenile fat snook Centropomus parallelus in cages at three densities. Boletim do Instituto de Pesca, Sao Paulo, 34: 319-324.

Universidad Nacional de Córdova (UNC). 2016. Corporation analytical service: InfoStat. Universidad Nacional de Córdova, Córdova.

Wedemeyer, G. 1996. Physiology of fish in intensive culture systems. Chapman \& Hall, New York.

Wells, R.M.G., Baldwin, J., Seymour, R.S., Christian, K. \& Brittain, T. 2005. Red blood cell function and haematology in two tropical freshwater fishes from Australia. Comparative Biochemistry and Physiology - Part A: Molecular \& Integrative Physiology, 141: 8793.

Wright, P.A. \& Land, M.D. 1998. Urea production and transport in teleost fishes. Comparative Biochemistry and Physiology - Part A: Molecular \& Integrative Physiology, 119: 47-54.

Wurts, W. 1995. Using salt to reduce handling stress in channel catfish. World Aquaculture, 26: 80-81. 